Mary Jane C. Tipayno, MD

Department of Otolaryngology

Philippine Children's Medical Center
Correspondence: Mary Jane C. Tipayno, MD Rm. 204 Notre Dame de Chartres Hospital General Luna Rd. 2600 Baguio City Philippines

Phone: 6198530 loc. 204/09175066561

E-mail: janetipaynomd@yahoo.com

Reprints will not be available from the author.

No funding support was received for this study. The author signed a disclosure that she has no proprietary or financial interest with any organization that may have a direct interest in the subject matter of this manuscript, or in any product used or cited in this study

Presented at the Philippine Children's Medical Center Annual Research Contest, Poster Category on November 5, 2007, Quezon City, Philippines

\section{A 10-Year Review of Brainstem Auditory Evoked Response Testing at the Philippine Children's Medical Center: Patient Demographics and Outcomes}

\author{
ABSTRACT \\ Objective: The study aims to present the clinical and demographic profile of subjects who have \\ undergone Auditory Brainstem Response (ABR) test at the Philippine Children's Medical Center \\ over a 10-year period.

\section{Methods:} \\ Design: Retrospective chart review \\ Setting: Tertiary children's hospital \\ Subjects: All patients referred for ABR testing from January 1996 to December 2005.
}

Results: A total of 2783 cases were included in the study with 1.63:1 male-to-female ratio. Almost $50 \%$ belonged to the 2-to 5-year-old age group. There were 111 different indications for referral, with speech and language disorders ranking first at 38\%. Patients with Congenital Rubella had the highest incidence of pathologic ABR results with $90.62 \%$. There was no significant difference in the degree of hearing loss between the pre-school (2-5 years old) and school age ( $>5$ to 10 years old) group. Our patients who presented with speech delay had a much older average age of hearing loss detection by ABR compared to foreign studies.

Conclusion: Speech and developmental delays were the leading causes for ABR referral across age groups with most belonging to the 2-to-5-year-old age group. There was no statistically significant difference in the degree of hearing loss between the preschool and school-age groups with speech delay. ABR in hearing screening of neonates and children constitutes only a small fraction of the total indications for ABR Testing at the Philippine Children's Medical Center. Detection of hearing loss at an earlier age may reveal the true burden of illness and facilitate earlier intervention. Universal hearing screening should be performed for all newborns and not just for high risk infants.

Key words: hearing loss, speech delay, Auditory Brainstem Response, ABR

The American Speech-Language Hearing Association estimates the prevalence of newborns with congenital hearing loss in the United States at between 1 to 6 per 1,000.1,2 The average age of detection in the pediatric population is between 12 and 25 months $^{3,4,5,6}$ with patients at risk and more severely impaired children being identified earliest. Children with no risk factors for hearing loss and children with mild to moderate hearing loss typically were not identified until about 28 months of age; with many undetected until identified at preschool and kindergarten 
hearing screening programs, or when hearing was tested because of concerns regarding speech, language and cognitive delays. The Joint Committee of Infant Hearing Year 2000 proposed that all infants born with hearing loss be screened by 1 month of age, diagnosed by 3 months and enrolled into early intervention by 6 months of age. This strong recommendation for early detection and intervention for infants with hearing loss cannot be overemphasized, as Yoshinaga-Itano and colleagues ${ }^{7}$ showed that children in whom hearing loss was identified, and remediation instituted before 6 months of age had significantly higher scores on tests of vocabulary, expressive language and language comprehension than those diagnosed after 6 months. The screening tools of choice for newborns include Oto-acoustic Emission (OAE) and Auditory Brainstem Evoked Response (ABR) tests, with the latter being more reliable for the difficult to test and for very young patients.

As one of the first local institutions to acquire an Auditory Brainstem Response (ABR) machine, the Philippine Children's Medical Center (PCMC) has tested children from all over the country for the past 13 years. The study aims to present the clinical and demographic profile of subjects who have undergone Auditory Brainstem Response (ABR) test at the Philippine Children's Medical Center over a 10-year period.

\section{RESEARCH OBJECTIVES}

\section{General Objective:}

To present the clinical and demographic profile of subjects who have undergone ABR test at PCMC from January 1996 to December 2005.

\section{Specific Objectives:}

1. To present $A B R$ patient distribution as to age, sex, working diagnosis (pertinent to $A B R$ testing/ reason for referral), source of referral (physician's specialty);

2. To determine the incidence and degree of auditory pathway pathology for the ten most common working diagnoses/indications for $A B R$ referral and compare them with existing international literature;

3. To rank the leading causes of referral for each age group over the 10-year period;

4. To determine the average age of auditory pathology detection by $A B R$ among patients presenting with speech delay over the 10-year period;

5. To determine if there is a significant difference in the degree of hearing loss detected during the preschool (2-5 years old) and school age (more than 5 years old) group of patients with speech delay;

6 . To determine the number of subjects 3 months and younger referred specifically for hearing screening and with no indicated risk factor/s for hearing loss; and

7. To present the most common reasons for referrals and degree of hearing loss in the neonatal age group.

\section{Operational Definition of Terms}

Hearing Loss- Hearing threshold greater than $35 \mathrm{~dB}$

Mild Hearing Loss- Hearing threshold more than 35 to less than $45 \mathrm{~dB}$

Moderate Hearing Loss- Hearing threshold at 45 to $65 \mathrm{~dB}$

Severe Hearing Loss- Hearing threshold more than 65 to less than $85 \mathrm{~dB}$

Severe to Profound Hearing Loss- Hearing threshold at $85 \mathrm{db}$ or more

\section{METHODOLOGY}

A retrospective review was conducted on charts of all patients who underwent ABR testing at the Philippine Children's Medical Center between January 1996 and December 2005. Patients with incomplete data pertinent to the information being collected were excluded. Patient data of interest included the following:

1. Patient name and case number

2. Age

3. Sex

4. Working diagnosis pertinent to ABR testing/reason for referral.

5. Source of referral as to physician's specialty

6. ABR findings

a. Degree of hearing loss (mild, moderate, severe, severe to profound)

b. Laterality (unilateral/bilateral) of deficit

The subjects were sub-grouped according to age level as follows:
a. 0 to less than 24 months
b. 24 months to 5 years old
c. More than 5 to 10 years old
d. More than 10 to 15 years old
e. More than 15 to 18 years old
f. More than 18 years old

Clinical impressions of speech and language disorders were consolidated under Speech Delay. Global Developmental Delay and Psychomotor Delay were labeled under Developmental Delay while PDD (Pervasive Developmental Delay) encompassed clinical of impressions of PDD, Autism, Autistic Spectrum Disorder and Rett Syndrome. Descriptive statistics using means and proportions were applied. The z- test of association was used to analyze the difference in the hearing loss detected during the preschool ( $2-5$ years old) from the school-aged group ( $>5$ to 10 years old) of patients with speech delay.

The ABR machine test parameters used were the following:

$$
\underline{\text { Stimulus Parameters }}
$$

$\begin{array}{ll}\text { Type: } & \text { Click } \\ \text { Duration: } & 100 \mu \mathrm{sec} \\ \text { Rate: } & 15 / \mathrm{sec} \\ \text { Polarity: } & \text { Alternating } \\ \text { Intensity: } & (100) 90,70,50 \text { and } 30 \mathrm{~dB} \\ \text { Transducer: } & \text { Elega TD 531 }\end{array}$

Acquisition Parameters Amplification : None Electrodes: $\quad$ Cz to Ipsilateral mastoid with forehead ground Filter settings: $100-3000 \mathrm{~Hz}$

Notch Filter: None

Number of Sweeps: 2000, replicated 
Table 1. Gender and Age Group Distribution

\begin{tabular}{|c|c|c|c|c|c|c|c|}
\hline & $\mathbf{0}-<24 \mathrm{~m}$ & $\mathbf{2 - 5 y}$ & $>\mathbf{5 - 1 0 y}$ & $>\mathbf{1 0 - 1 5 y}$ & $>\mathbf{1 5 - 1 8 y}$ & $>$ 18y & Total \\
\hline Female & 343 & 490 & 177 & 37 & 2 & 7 & 1057 \\
\hline Male & 480 & 912 & 290 & 36 & 2 & 7 & 1726 \\
Total & 823 & 1402 & 467 & 73 & 4 & 14 & 2783 \\
\hline
\end{tabular}

Figure 1. Age Group Distribution

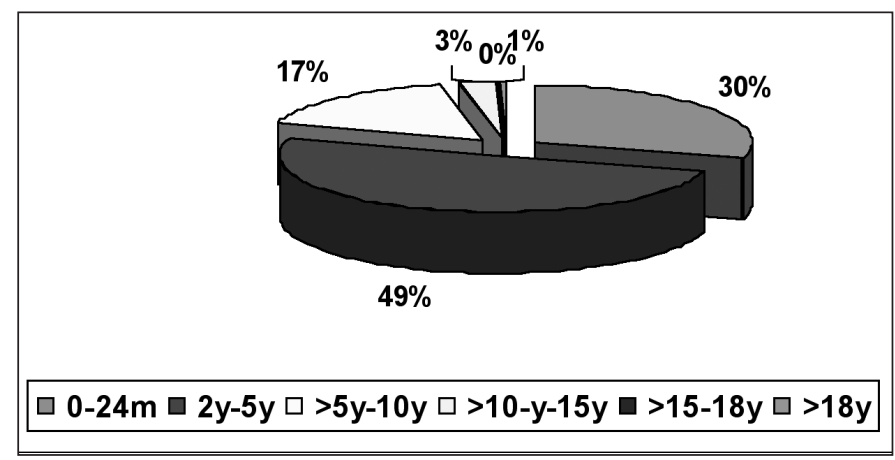

Figure 2. Percent Distribution of ABR Indications

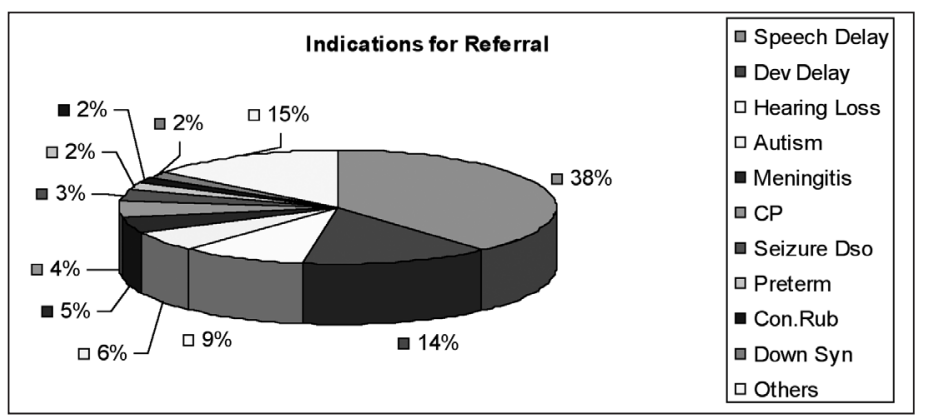

The average age of auditory pathology detection was determined by taking the total age in months of the affected patients at the time of detection divided by the total number of affected patients.

\section{RESULTS}

A total of 2783 patients were included in the study with an overall female to male ratio of 1:1.63 (Table 1). The 2-to-5 year-old age group was largest, making up 49\% (Figure I). There were 111 total listed indications for referral. Close to $85 \%$ of the total cases were shared by the top 10 clinical entities; of these, 38\% were represented by the Speech Delay Disorders (Appendix I, Figure 2). The remaining $15 \%$ were shared by 101 other indications. Sixty-one percent of the referring physicians were residents and fellows, child neurology consultants contributed sixteen percent $16 \%$ followed by neurodevelopmental pediatricians and otolaryngologists with 8 and $4 \%$, respectively (Figure3).

The incidence and degree of pathologic $A B R$ results for the 10 leading indications are listed in table 2. Table 3 shows comparative results with selected foreign studies on these 10 indications of referral. No direct comparison could be found in published studies regarding $A B R$ results of patients with seizure disorder per se and patients primarily suspected for hearing loss. Table 4 shows the most common causes for ABR referral for each age group. Global developmental delay was the primary reason for referrals in subjects under 2 years old, followed by speech delay. Bacterial meningitis was also a notable cause in this age group. Speech delay was the leading indication for ages 2-10 years old while hearing loss dominated the older age group.

The overall average age of auditory pathology detection in speechdelayed patients was 46.48 months, with no trend observed in the yearly average age of auditory pathology detection except for a peak in 2002 (Appendix 2, Figure 4). For all degrees of hearing loss, there was a slight increase in the $>5$-10-year-old age group compared to the 25-year-old age group (Table 5). These differences were not statistically significant using the $z$ - test of association (Appendix 3a, 3b).

Table 2: Incidence and Degree of Auditory Pathology of Top 10 Ranked ABR Referrals

\begin{tabular}{|c|c|c|c|c|c|c|c|c|c|c|c|c|c|c|}
\hline \multirow[t]{3}{*}{$\begin{array}{l}\text { Indication for } \\
\text { Referral }\end{array}$} & \multicolumn{2}{|c|}{ Total } & \multicolumn{10}{|c|}{$\begin{array}{c}\text { Results } \\
\text { (Ears tested) }\end{array}$} & \multicolumn{2}{|c|}{$\begin{array}{c}\text { Total } \\
\text { Incidence }\end{array}$} \\
\hline & \multirow[t]{2}{*}{$\begin{array}{l}\text { Patients } \\
\text { Tested }\end{array}$} & \multirow[t]{2}{*}{$\begin{array}{l}\text { Ears } \\
\text { Tested }\end{array}$} & \multicolumn{2}{|c|}{ Intact } & \multicolumn{2}{|c|}{ Mild HL } & \multicolumn{2}{|c|}{$\begin{array}{c}\text { Moderate } \\
\text { HL }\end{array}$} & \multicolumn{2}{|c|}{ Severe HL } & \multicolumn{2}{|c|}{$\begin{array}{c}\text { Severe to } \\
\text { Profound HL }\end{array}$} & \multirow[t]{2}{*}{$\mathbf{N}$} & \multirow[t]{2}{*}{$\%$} \\
\hline & & & $\mathbf{N}$ & $\%$ & $\mathbf{N}$ & $\%$ & $\mathbf{N}$ & $\%$ & $\mathrm{~N}$ & $\%$ & $\mathrm{~N}$ & $\%$ & & \\
\hline Speech Delay & 1073 & 2146 & 1350 & 62.91 & 90 & 4.19 & 142 & 6.62 & 119 & 5.54 & 445 & 20.74 & 796 & 37.09 \\
\hline GDD & 391 & 782 & 530 & 67.77 & 45 & 5.75 & 66 & 8.44 & 26 & 3.32 & 115 & 14.71 & 252 & 32.23 \\
\hline HL & 259 & 518 & 139 & 26.83 & 10 & 1.93 & 20 & 3.86 & 34 & 6.56 & 315 & 60.81 & 379 & 73.17 \\
\hline Autism & 163 & 326 & 303 & 92.94 & 10 & 3.30 & 6 & 1.98 & 0 & 0 & 9 & 2.97 & 25 & 7.67 \\
\hline Meningitis & 128 & 256 & 165 & 64.45 & 19 & 7.42 & 20 & 7.81 & 7 & 2.73 & 45 & 17.58 & 91 & 35.55 \\
\hline$C P$ & 124 & 248 & 137 & 55.24 & 6 & 2.42 & 16 & 6.45 & 2 & 0.81 & 87 & 35.08 & 111 & 44.76 \\
\hline Seizure & 92 & 184 & 152 & 82.61 & 7 & 3.8 & 8 & 4.35 & 3 & 1.63 & 14 & 7.61 & 32 & 17.39 \\
\hline PT & 55 & 110 & 61 & 55.45 & 6 & 5.54 & 9 & 8.18 & 6 & 5.54 & 28 & 25.45 & 49 & 44.55 \\
\hline Con. Rubella & 48 & 96 & 9 & 9.38 & 5 & 5.20 & 5 & 5.20 & 12 & 12.50 & 65 & 67.71 & 87 & 90.62 \\
\hline Down & 47 & 94 & 44 & 46.81 & 9 & 9.57 & 22 & 23.40 & 4 & 4.26 & 15 & 15.96 & 50 & 53.19 \\
\hline
\end{tabular}


There were 57 (2\%) patients aged 3 months and younger in the study, 4 of these were well babies, specifically referred for hearing screening. It is interesting to note that in patients 6 months and under, 7 were referred as follow ups to a "refer" result of a previous otoacoustic emission test.

Only $6(0.22 \%)$ neonates were referred, 2 for aural atresia and 1 each for bacterial meningitis, prematurity, cerebral palsy and sepsis.

\section{DISCUSSION}

Speech and developmental delays were the leading causes for ABR referral across age groups with most (almost 50\%) belonging to the 2-to-5-year-old age group. Because intelligible speech is expected from a child of this age, verbal delay prompts parents and guardians to consult. Abnormal ABR results for speech delay in our study were more than twice those of a European study. ${ }^{8}$ Congenital Rubella syndrome presented with the highest incidence of abnormal $A B R$ results at $90.62 \%$, slightly higher than that published by Roizen in $1999^{9}$ while Niedzielska ${ }^{10}$ and Sadijhi, J. et al ${ }^{11}$ reported a much lower incidence. Our results for hearing loss in children with global developmental delay fell within the wide range of other studies exemplified by Haggard ${ }^{12}$ and Rupa. ${ }^{13}$ Our incidences for autism were $5.28 \%$ and $2.97 \%$ for mild to moderate, and severe to profound hearing loss, respectively, lower than the $7.9 \%$ and $3.5 \%$ reported by Rosenhall ${ }^{14}$ in a European population. Taylor $^{15}$ similarly showed a higher incidence in his study considering only autistic children without associated features.

Bacterial meningitis was the most common reason among the infectious causes for ABR referral. The incidence of hearing loss as a sequel of bacterial meningitis were reported at $10 \%$ by Tarlow $^{16}$ and $7 \%$ by Koomen, ${ }^{17}$ much lower than our results which were similar to those conducted at a children's hospital in Nepal. ${ }^{18}$ Our results of more than $50 \%$ abnormal ABR in Down syndrome support the consistently high incidence of hearing impairment in this clinical entity as diagnosed by ABR. ${ }^{19,20}$ We had a $44.55 \%$ incidence of abnormal ABR in cerebral palsy patients, twice higher than the findings of Robinson ${ }^{21}$ and Zafeiriou ${ }^{22}$ and much higher than the 2-6\% average incidence of hearing loss in the preterm infant population reported elsewhere. ${ }^{23} \mathrm{It}$ is possible that co-morbid conditions in a majority of our patients with cerebral palsy may have increased the incidence of abnormal $A B R$ results. While the incidence of abnormal ABR results for developmental delays, post bacterial meningitis, Down syndrome and congenital Rubella were at par with foreign statistics, our incidence for autism was slightly lower. The myriad etiologies for, and different classifications of seizure disorders precluded making any direct comparisons with the literature.

No trend was noted on the average age of hearing loss detected in speech-delayed patients with respect to time; the peak average in year 2000 was attributed to an adult patient tested. Our results showed that we are 21 to 34 months behind the world's average age of detecting hearing loss in the pediatric population using speech delay as the presenting symptom. Reasons for late consultation may include a lack of awareness of the early signs of hearing loss on the part of parents and guardians. On the other hand, significant observations of concerned parents may have been disregarded by well-meaning health care givers
Table 3. Comparative Table on the Incidence of Patholigic Results of Top 10 Ranked ABR Referrals

\begin{tabular}{|c|l|l|l|}
\hline RANK & INDICATION & PCMC & FOREIGN STUDIES \\
\hline $\mathbf{1}$ & Speech Delay & 37.09 & 13.3 (Psarommatis I.M. et al, 2001) \\
\hline $\mathbf{2}$ & GDD & 32.23 & $\begin{array}{l}18 \text { (Haggard M. 1992) } \\
91 \text { (Rupa V. 1995) }\end{array}$ \\
\hline $\mathbf{3}$ & HL & 73.17 & $* *$ \\
\hline $\mathbf{4}$ & Autism & 7.96 & $\begin{array}{l}9.5 \text { (Rosenthal et al, 1999) } \\
18.75 \text { (Taylor et al, 1982) }\end{array}$ \\
\hline $\mathbf{5}$ & Meningitis & 35.55 & $\begin{array}{l}10 \text { (Tarlow, 1997) } \\
36 \text { (Kanti Children's Hospital, 1984) } \\
7 \text { (Koomen l., Grobbee et. al 2003) }\end{array}$ \\
\hline $\mathbf{6}$ & CP & 44.76 & $\begin{array}{l}20 \text { (Robinson, 1983) } \\
22.7 \text { (Zafeiriou, 1999) }\end{array}$ \\
\hline $\mathbf{7}$ & Seizure & 17.39 & $*$ \\
\hline $\mathbf{8}$ & PT & 44.55 & 2-6 (JCIH, 1994) \\
\hline $\mathbf{9}$ & Down & 53.19 & $\begin{array}{l}66 \text { (Roizen, 1997) } \\
>75 \text { (Cunningham \& McArthur 1981) }\end{array}$ \\
\hline $\mathbf{1 0}$ & Con Rubella & 90.62 & $\begin{array}{l}50 \text { (Neidzieska, 1999) } \\
90 \text { (Roizen, 1999) } \\
12 \text { (Sadijhi,J. et al, 2004) }\end{array}$ \\
\hline
\end{tabular}

Figure 3. Distribution of Referral Source

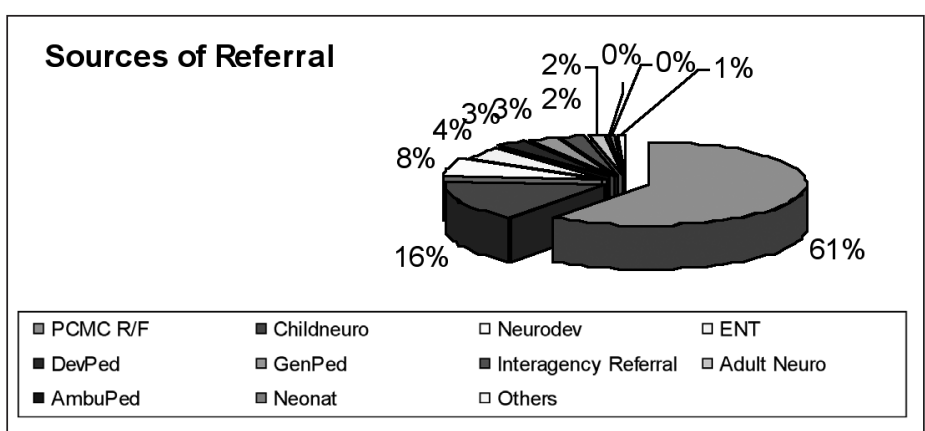

Figure 4. Yearly Average Age of Auditory Pathology Detection in Patients Presenting with Speech Delay

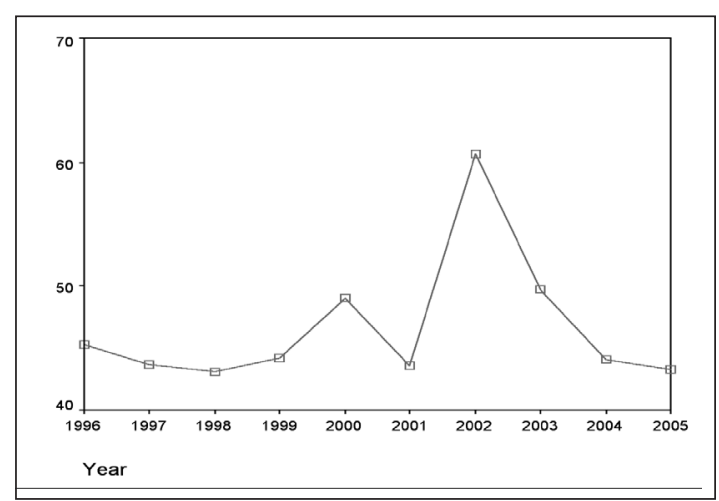


Table 4. Ranked Leading Causes of Referral for Each Age Group

\begin{tabular}{|c|c|c|c|c|c|c|c|c|c|c|c|c|}
\hline \multirow[b]{2}{*}{ Rank } & \multicolumn{2}{|c|}{$0-<24$ Mos } & \multicolumn{2}{|c|}{$2-5 y / 0$} & \multicolumn{2}{|c|}{$>5-10 \mathrm{y} / 0$} & \multicolumn{2}{|c|}{$>10-15 \mathrm{y} / 0$} & \multicolumn{2}{|c|}{$>15-18 \mathrm{y} / 0$} & \multicolumn{2}{|c|}{$>18 \mathrm{y} / 0$} \\
\hline & COR & $\mathrm{N}$ & COR & $\mathrm{N}$ & CoR & $\mathrm{N}$ & COR & $\mathrm{N}$ & CoR & $\mathrm{N}$ & COR & $\mathrm{N}$ \\
\hline 1 & GDD & 153 & SD & 754 & SD & 183 & $\mathrm{HL}$ & 16 & $\mathrm{HL}$ & 2 & $\mathrm{HL}$ & 3 \\
\hline 2 & SD & 118 & GDD & 173 & $\mathrm{HL}$ & 67 & SD & 15 & - & - & - & - \\
\hline 3 & Men & 83 & PDD & 125 & PDD & 61 & GDD & 8 & - & - & - & - \\
\hline 4 & $C P$ & 69 & HL & 113 & GDD & 56 & MR & 8 & - & - & - & - \\
\hline 5 & HL & 59 & $C P$ & 47 & MR & 27 & Men & 4 & - & - & - & - \\
\hline 6 & $\mathrm{Sz}$ & 33 & $\mathrm{Sz}$ & 37 & $\mathrm{Sz}$ & 18 & PDD & 3 & - & - & - & - \\
\hline 7 & PT & 31 & Men & 33 & Men & 11 & OM & 3 & - & - & - & - \\
\hline 8 & ConRu & 29 & CoRu & 15 & $C P$ & 6 & $\mathrm{Sz}$ & 3 & - & - & - & - \\
\hline 9 & DoSy & 29 & Dosy & 14 & HyBil & 5 & - & - & - & - & - & - \\
\hline 10 & HyBil & 27 & HyBil & 9 & CoRu & 3 & - & - & - & - & - & - \\
\hline & & & & & $\mathrm{HCP}$ & 3 & & & & & & \\
\hline & & & & & $\mathrm{OM}$ & 3 & & & & & & \\
\hline
\end{tabular}

Legend:

$\begin{array}{llll}\text { CoR } & \text { Cause of Referral } & \text { Sz } & \text { Seizure Disorder } \\ \text { GDD } & \text { Global Developmental Delay } & \text { PT } & \text { Prematurity } \\ \text { SD } & \text { Speech Delay } & \text { CoRu } & \text { Congenital Rubella } \\ \text { Men } & \text { Meningitis } & \text { DoSy } & \text { Down Syndrome } \\ \text { CP } & \text { Cerebral Palsy } & \text { HyBil } & \text { Hyperbilirubinemia } \\ \text { HCP } & \text { Hydrocephalus } & \text { OM } & \text { Otitis Media } \\ \text { HL } & \text { Hearing Loss } & \text { MR } & \text { Mental Retardation }\end{array}$

Table 5. Degree of Hearing Loss in Preschool (2-5 y/o) and School Aged (>5-10 y/o) Group with Speech Delay

\begin{tabular}{|c|c|c|c|c|c|c|c|c|c|c|c|c|c|}
\hline \multirow{4}{*}{$\begin{array}{l}\text { Age } \\
\text { Grp }\end{array}$} & \multirow{4}{*}{$\begin{array}{l}\text { Patients } \\
\text { Tested }\end{array}$} & \multirow{4}{*}{$\begin{array}{c}\text { Ears } \\
\text { Tested }\end{array}$} & \multicolumn{11}{|c|}{ Result (Ears Tested) } \\
\hline & & & \multirow{3}{*}{$\begin{array}{l}\text { Inact } \\
\mathrm{N}\end{array}$} & \multicolumn{8}{|c|}{ Abnormal Auditory Pathway } & \multirow{3}{*}{ Total } & \multirow{3}{*}{$\%$} \\
\hline & & & & \multicolumn{2}{|c|}{ Mild } & \multicolumn{2}{|c|}{ Mod } & \multicolumn{2}{|c|}{ Severe } & \multicolumn{2}{|c|}{ Sev-Pro } & & \\
\hline & & & & N & $\%$ & $\mathbf{N}$ & $\%$ & $\mathbf{N}$ & $\%$ & $\mathrm{~N}$ & $\%$ & & \\
\hline $2-5 y 0$ & 760 & 1520 & 1006 & 59 & 3.88 & 87 & 5.72 & 89 & 5.86 & 279 & 18.36 & 514 & 33.82 \\
\hline$>5-10 y_{0}$ & 183 & 366 & 200 & 20 & 5.46 & 31 & 8.47 & 23 & 6.28 & 92 & 25.14 & 166 & 45.36 \\
\hline Pvalue & & & & \multicolumn{2}{|c|}{$>.05$} & \multicolumn{2}{|c|}{$>.05$} & \multicolumn{2}{|c|}{$>.05$} & \multicolumn{2}{|c|}{$>.05$} & & \\
\hline
\end{tabular}

Appendix 1. Percent Distribution of ABR Referral Indications

\begin{tabular}{|c|c|c|c|c|c|c|c|c|c|c|c|c|}
\hline Cases & SD & DD & HL & PDD & Men & CP & $\begin{array}{l}\mathrm{Sz} \\
\mathrm{D}\end{array}$ & PT & CR & DS & 이 & Total \\
\hline Female & 349 & 185 & 113 & 32 & 51 & 59 & 35 & 20 & 25 & 21 & 166 & $\begin{array}{r}1056 \\
(38 \%)\end{array}$ \\
\hline Male & 724 & 206 & 146 & 131 & 77 & 65 & 57 & 35 & 22 & 26 & 240 & $\begin{array}{c}1729 \\
(62 \%)\end{array}$ \\
\hline $\begin{array}{l}\text { Total } \\
(\%)\end{array}$ & $\begin{array}{c}1073 \\
38.53\end{array}$ & $\begin{array}{c}391 \\
14.04\end{array}$ & $\begin{array}{l}259 \\
9.30\end{array}$ & $\begin{array}{c}163 \\
5.85\end{array}$ & $\begin{array}{l}128 \\
4.60\end{array}$ & $\begin{array}{l}124 \\
4.45\end{array}$ & $\begin{array}{c}92 \\
3.30\end{array}$ & $\begin{array}{c}55 \\
1.97\end{array}$ & $\begin{array}{c}47 \\
1.69\end{array}$ & $\begin{array}{c}47 \\
1.69\end{array}$ & \begin{tabular}{|l|}
406 \\
14.58 \\
\end{tabular} & 2785 \\
\hline
\end{tabular}

Legend:

$\begin{array}{ll}\text { SD } & \text { Speech delay } \\ \text { DD } & \text { Developmental Delay } \\ \text { HL } & \text { Hearing Loss } \\ \text { PDD } & \text { Pervasive Developmental Delay } \\ \text { Men } & \text { Meningitis }\end{array}$

Sz D Seizure Disorder PT Prematurity

CR Congenital Rubella

DS Down Syndrome

$\mathrm{CP}$ Cerebral Palsy who downplayed the possibility of hearing loss. Costs associated with hearing screening may also contribute to delay. Although it may be posted that a more severe degree of hearing loss in younger patients prompts earlier referral than among school-aged children in whom it was usually an incidental finding, this was not the case in our study. Further, there was no statistically significant difference in the degree of hearing loss between the preschool and school age groups with speech delay.

Less than $1 \%$ of the overall indications for referral were for follow-up of failed hearing screening and only $2 \%$ of the subjects were 3 months old and younger. These values may reflect the minimal usage of $A B R$ for hearing screening in our institution as well as a lack of awareness of the importance of newborn hearing screening in general. This may be exacerbated by the absence of a mandate to screen all newborns for potential hearing loss, and not just the high risk group as traditionally done. An important study among patients with congenital hearing loss showed that $50 \%$ did not have any risk factors. ${ }^{24}$ Apart from delayed cognitive complications of hearing loss, economic and societal repercussions are not to be disregarded. It is estimated in an American study that households lose $\$ 122$ billion in lost income and reduced federal tax revenues by another $\$ 18.4$ billion. ${ }^{25}$

$A B R$ in hearing screening of neonates and children constitutes only a small fraction of the total indications for ABR Testing at the Philippine Children's Medical Center. Detection of hearing loss at an earlier age may reveal the true burden of illness and facilitate earlier intervention. Finally, to improve on the poor average age of hearing loss detection so that subsequent remedial measures are administered, it is strongly recommended that universal hearing screening be performed for all newborns and not just for high risk infants. 
Appendix 2. 10-year average age (months) of speech delay diagnosis

\begin{tabular}{|c|c|c|c|c|c|c|c|c|c|c|c|}
\hline & 1996 & 1997 & 1998 & 1999 & 2000 & 2001 & 2002 & 2003 & 2004 & 2005 & Overall \\
\hline Cases & 112 & 87 & 166 & 73 & 100 & 93 & 94 & 127 & 122 & 99 & 1073 \\
\hline Average & 45.28 & 43.63 & 43.1 & 44.15 & 49.05 & 43.56 & 60.66 & 49.69 & 44.03 & 43.31 & 46.48 \\
\hline
\end{tabular}

\section{Appendix 3a. Cross tabulation of preschool and school-aged group with speech delay}

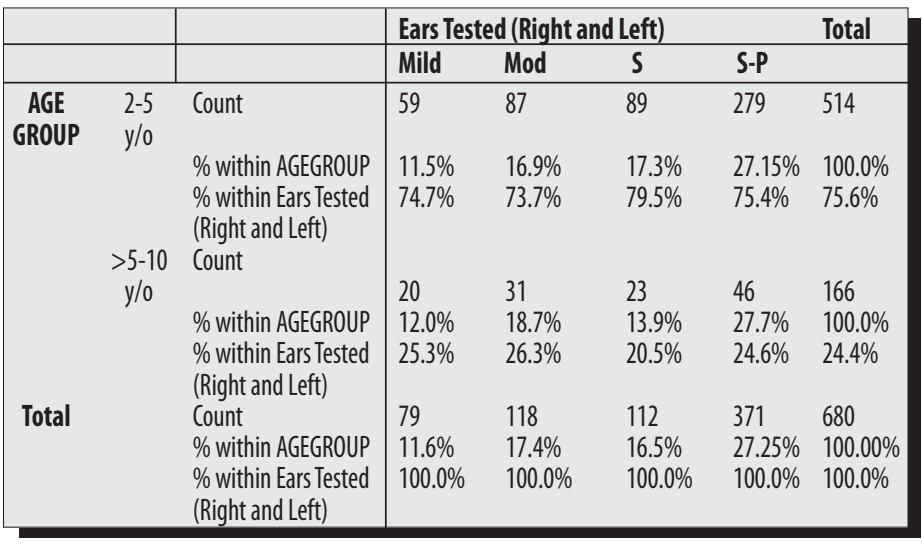

Appendix 3b. p Value using z-test of association

\begin{tabular}{|c|l|l|l|l|}
\hline & Mild & Mod & S-P & SP \\
\hline $\mathbf{2 - 5} \mathbf{y} / \mathbf{0}$ & 11.47859922 & 16.92607004 & 17.3151751 & 22.95719844 \\
$>\mathbf{5 - 1 0} \mathbf{y} / \mathbf{0}$ & 12.04819277 & 18.6746988 & 13.85542169 & 21.68674699 \\
Difference & -0.56959355 & -1.748628756 & 3.459753411 & 1.270451456 \\
p value & $>.05$ & $>.05$ & $>.05$ & $>.05$ \\
Conclusion & not significant & not significant & not significant & not significant \\
\hline
\end{tabular}

\section{Appendix 4. Patient Data Collection Form}

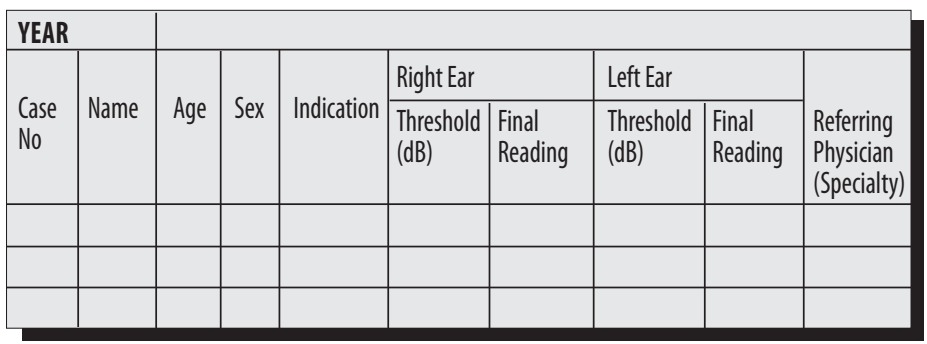

\section{ACKNOWLEDGEMENTS}

My heartfelt thanks to my kind mentors, Drs. Adonis B. Jurado, Gretchen Navarro-Locsin, and Ma. Rina T. Reyes-Quintos, to my technical adviser Paul Matthew Pasco and the Research Development Board of PCMC, the staff of the PCMC Neurodiagnostic lab, my loving family and finally to the Almighty who made all these things possible.

\section{REFERENCES}

1. Kemper AR and Downs SM. A cost effectiveness analysis of newborn hearing screening strategies. Arch Pediatr Adol Med, 2000 May; 154(5): 484-488.

2. Cunningham M, Cox EO. Hearing assessment in infants and children: Recommendations beyond neonatal screening. Pediatrics, 2003 February; 111(2): 436-440.

3. Elsmann S, Matkin N, Sabo M. Early identification of congenital sensorineural hearing impairment. Hearing Journal 1987; 40: 13.

4. Harrison M, Roush J. Age of suspicion, identification and intervention for infants with hearing loss: a national study. Ear Hearing 11:210, 1990.

5. Mace A, Wallace K, Whan M, Stelmachowicz P. Relevant factors in the identification of hearing loss. Ear Hearing 1991; 12: 287.

6. Stein LK, Jabaley T, Spitz R, Stoakley D. and McGee T. (1990). The hearing-impaired infant: Patterns of identification and rehabilitation revisited. Ear Hearing, 11 (3), 201-205.

7. Yoshinaga-Itano C, Sedey AL, Coulter DK and Mehl A L. The effect of early identification on the development of deaf and hard of hearing infants and toddlers. Poster presented at the American Academy of Audiology Conference. Salt Lake City, 1996

8. Psarommatis IM, Goritsa E, Douniadakis D, Tsakanikos M, Kontrogianni AD and Apostoloulos N. Hearing loss in speech-language delayed children. Int J Pediatr Otorhi. Vol 58, issue 3, May 2001 pp 205-210.

9. Roizen NJ. Etiologies of hearing loss in children. Non genetic causes. Pediatr Clin N Am 1999 Feb; 46(1):pp49-64.

10. Niedzielska G, Ktska E and Szymula D. Hearing defects in children born of mothers suffering from rubella in the first trimester of pregnancy. Int J Pediatr Otorhi Vol 54, issue, Aug, 2000 pp15.

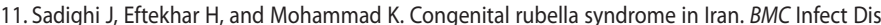
2005; 5: 44.

12. Haggard M. Screening children's hearing. Brit J Audiol 1992; 26: 209-215

13. Rupa V. Dilemmas in auditory assessment of developmentally retarded children using behavioral observation audiometry and brainstem evoked response audiometry. J Laryngol Otol 1995: 109:605-609.

14. Rosenhall V., Sandström M, Ahlsén ${ }^{G}$ and Gillberg C. Autism and hearing loss.J Autism Dev Disord. Volume 29, Number 5, 1999. Publisher Springer Netherlands ISSN 0162-3257 (Print) 1573-3432 (Online)

15. Taylor MJ, Rosenblatt B, Linschoten L. Auditory Brainstem Response Abnormalities in Autistic Children. Can J Neurol Sci 1982; 9:429-433.

16. Richardson MP, Reid A., Tarlow M J, Rudd PT. Hearing loss during bacterial meningitis . Arch Dis Child February 1997; 76:134-138.

17. Koomen I, Grobbee DE, Roord JJ, Donders R, Schinkel AJ and van Furth AM. Hearing loss at school age in survivors of bacterial meningitis: assessment, incidence, and prediction. Pediatrics. 2003; 112:1049-1053.

18. Unknown Author. Available at: http://www.healthnet.org.np/gsdl/collect/thesis/index/assoc/ HASH0123.dir/doc.pdf

19. Roizen N. Hearing loss in children with Down's syndrome: a review. Down syndrome Quarterly.1997.2(4).1-4.

20. Cunningham C, McArthur K. Hearing loss and treatment in young Down's syndrome children Child: care, health and development 1981.7: 357-374

21. Robinson RO. The frequency of other handicaps in children with cerebral palsy. Developmental Medicine and Child Neurology. No. 15, 1983. pps. 305-312.

22. Zafetriou DI, Andreou A, Karasavidou K. Utility of brainstem auditory evoked potentials in children with spastic cerebral palsy. Acta Paediatrica Vol. 89 Issue 2 Pages 194-197, February 2000.

23. Joint Committee on Infant Hearing, American Academy of Audiology, American Academy of Pediatrics, American Speech-Language-Hearing Association, and Directors of Speech and Hearing Programs in State Health and Welfare Agencies. Position statement: principles and guidelines for early hearing detection and intervention programs. Pediatrics. 2000; 106: 798817.

24. Mehl AL and ThomsonV.Newborn Hearing Screening: The Great Omission. Pediatrics Vol. 101 No.1 January 1998, p.e4

25. Kochkin S. The high cost of hearing loss. Hearing Journal. October 2005.Available at: http:// findarticles.com/p/articles/mi hb3496/is_200701/ai_n18863242. 